\title{
13. COMPOSITION AND ORIGIN OF SEDIMENTS RECOVERED BY DEEP DRILLING OF SEDIMENT MOUNDS, GALAPAGOS SPREADING CENTER
}

\author{
Jack Dymond, John B. Corliss, Richard Cobler, Charlotte Meredith Muratli, \\ Christin Chou, and Roberta Conard, School of Oceanography, Oregon State University, Corvallis, Oregon
}

\begin{abstract}
The sediments recovered on Deep Sea Drilling Project Leg 54 appear to be mixtures of the normal pelagic sediments of the area and hydrothermally produced manganese and iron phases. The latter are mineralogically and chemically very similar to phases recovered from surficial sampling of the mounds. The hydrothermal nontronite which is approximately 15 meters thick in the three holes is essentially free of carbonate or detrital contaminants. The basal sediments are similar to the carbonate oozes presently being deposited in the region, but are enriched in $\mathrm{Mn}$ and $\mathrm{Fe}$. This enrichment appears to be the result of hydrothermal deposition that took place at or near the spreading center and may not be associated with the mounds formation.

Three different hypotheses for the formation of the nontronite layer and the mounds deposits are considered. An initial deposition of a widespread nontronite layer and subsequent diapiric-like movement of the layer into carbonates could account for the observed stratigraphy; however, if this be correct, analogous deposits should be present in other DSDP sites. The second hypothesis-replacement of the normal sediments by nontronite-may be feasible, but the high purity of the nontronite requires dissolution and removal of refractory elements. The third hypothesis, metal deposition in an advancing oxidation gradient, is compatible with submersible observations of the mounds; however, it can account only for the high purity of the nontronite by very rapid deposition of the hydrothermal phases.
\end{abstract}

\section{INTRODUCTION}

Sediment samples from Holes 424, 424A, and 424B (see Table 1) were analyzed for comparison with samples recovered from the same area by shallow coring, dredging, and the Alvin submersible. Published studies of the composition of these materials (Corliss et al., 1978) have been limited to crusts obtained by dredging over the general mounds field previously delineated by deep-tow studies (Klitgord and Mudie, 1974; Lonsdale, 1977). The crusts recovered by dredging consisted of manganese and iron phases in a variety of morphologies. Exceptionally pure and well-crystallized todorokite and birnessite are the most common manganese phases, while an Al-poor nontronite is the most common iron-bearing phase. Some crusts contain X-rayamorphous iron material having significant amounts of Mn (7 to $8 \%$ ) and $\mathrm{Si}(11$ to $15 \%)$. The exceptional crystallinity and very low abundances of elements such as $\mathrm{Cu}, \mathrm{Ni}, \mathrm{Zn}$, and $\mathrm{Co}$ are consistent with formation from sea-water hydrothermal systems which have percolated through the sediments from the underlying basalt.

Sampling and observations made from Alvin established that the surfaces of the mounds generally have massive to thin ferromanganese crusts underlain by green nontronite (Corliss et al., 1979; Williams et al., 1979). A thin layer of the normal biogenic carbonatesiliceous sediment covers much of the manganese-rich crusts. Although strong flows of hydrothermal fluids were not observed with Alvin, seepages of fluid with temperatures of 2 to $8^{\circ} \mathrm{C}$ above bottom water were measured after punching holes with the heat flow probe. Many heat-flow measurements made near or on the mounds exhibited nonlinear thermal gradients, indicating the importance of convection. Using a one-dimensional convective and conductive heat-flow model, Williams et al. (1979) have computed total heat flows greater than several hundred heat flow units for samples taken near mounds axes.

The Leg 54 Scientific Party (Natland et al., 1979) have suggested that the mounds represent diapiric-like emplacements of hydrothermally deposited nontronite. This hypothesis was made primarily because the green nontronite occurred between calcareous siliceous ooze sediments in the mounds Holes 424 and $424 \mathrm{~A}$ as well as in Hole 424B, which was deliberately placed between mounds. Natland et al. (1979) suggest this layer was deposited 200,000 to 300,000 years ago and extends over 
TABLE 1

Samples Analyzed

\begin{tabular}{lcc}
\hline $\begin{array}{c}\text { Sample } \\
\text { Interval in cm) }\end{array}$ & $\begin{array}{c}\text { Depth in Core } \\
(\mathrm{cm})\end{array}$ & $\begin{array}{c}\text { Identification } \\
\text { Number }\end{array}$ \\
\hline Hole 424 & & \\
$1-1,144-146^{\mathrm{a}}$ & 145 & GS 2659 \\
$2-4,47-49$ & 1448 & GS 2661 \\
$4-6,79-81$ & 3080 & GS 2665 \\
Hole 424A & & \\
$1-1,110-116^{\text {a }}$ & 113 & GS 2658 \\
$2-2,2-4$ & 1653 & GS 2660 \\
$3-4,47-51$ & 2799 & GS 2663 \\
Hole 424B & & \\
$1-1,5-7 \mathrm{a}$ & & GS 2657 \\
$3-4,53-55$ & 6 & GS 2662 \\
$4-4,121-123$ & 2822 & GS 2664 \\
\hline a Depth in these samples is more uncertain because \\
of poor core recovery in the core top.
\end{tabular}

an area larger than the surficial mounds deposits. They suggest two seismic reflectors at, respectively, 7 and 15 meters mark the distribution of the nontronite layer and imply that it extends north and south of the mounds area.

Although there is little doubt that the mounds deposits have formed in response to hydrothermal processes, the causative mechanism is uncertain. Are the mounds the loci of active hydrothermal vents or do they represent diapiric-like emplacement through the carbonates of an earlier deposited hydrothermal layer? Do hydrothermal fluids interact and leach elements from the sediments, or is the source of metals largely from interactions between basalt and sea water? What conditions control the location and morphology of these unusual deposits? In this paper we will consider these questions in relation to the chemical and mineralogical composition of samples recovered during the DSDP work in the mounds area.

\section{SAMPLES AND DATA}

Table 1 lists the samples analyzed in this study. Their compositions were determined by instrumental activation analysis (INAA) (Gordon et al., 1968) and atomic absorption spectrometry analysis (AAS) (Dymond et al., 1977). The precision of the two techniques varies from a few per cent for $\mathrm{Al}, \mathrm{Si}, \mathrm{Fe}, \mathrm{Mn}$, and Co to 5 to 20 per cent for the trace elements. Comparison between the techniques was made for $\mathrm{Fe}$ and $\mathrm{Ba}$, and the similarity of results suggests these data have no systematic errors. Selective leaching of most of the samples was carried out to distinguish compositional influences of detrital and well-crystallized components from amorphous, poorly crystalline, and carbonate components. The hydroxylamine hydrochloride-acetic acid leach procedure of Chester and Hughes (1967) was followed. $\mathrm{CaCO}_{3}$ was determined by measuring the quantity of carbon dioxide generated by dissolution of the sample with hydro- chloric acid. The salt content was computed by measuring the water content and assuming a 35 -per-mil salinity.

Three samples were selected from each of the Holes 424, 424A, and 424B. As discussed by Natland et al. (1979), Holes 424 and 424A are believed to have been drilled on mounds, while Hole 424B was deliberately placed between linear rows of mounds that had been identified by earlier deep-tow surveys (Lonsdale, 1977). At each site a sample was chosen from near the surface, from the middle of the section in the green nontronite layer, and from the basal carbonate ooze overlying basaltic basement.

The near-surface sediment from Hole 424 (GS 2659) was observed to be composed of two components: green to greenish brown grains and a black, presumably manganese-rich phase. The coarsest black components were hand-picked from the sample and analyzed separately (GS 2659B) from the remaining green material which was estimated to be 94 per cent of the sample (GS 2659A).

Qualitative mineralogical compositions (Table 2) were determined by slow-scan X-ray diffraction (XRD). The three basal samples and the surface sample from Hole 424B were treated with buffered acetic acid prior to XRD to remove any calcite. Random powder mounts were scanned between 4 and $65^{\circ} 2 \theta$. Surface layers are a complex mixture of nontronite, detrital plagioclase, and quartz with varying amounts of todorokite or birnessite. Basal layers have similar mineralogical contents with generally less nontronite and crystalline Mn oxides in comparison with the surface samples. The samples from near the middle of the three holes (GS 2660, GS 2661,

TABLE 2

Qualitative X-Ray Diffraction Data ${ }^{\mathrm{a}}$

\begin{tabular}{lcccccc}
\hline Sample & $\begin{array}{c}\text { Nontro- } \\
\text { nite }\end{array}$ & $\begin{array}{c}\text { Todoro- } \\
\text { kite }\end{array}$ & $\begin{array}{c}\text { Birnes- } \\
\text { site }\end{array}$ & Albite & Quartz & $\begin{array}{c}\text { Cal- } \\
\text { cite }\end{array}$ \\
\hline $2659 \mathrm{e}$ & - d & $-\mathrm{a}$ & $-\mathrm{a}$ & $-\mathrm{d}$ & $-\mathrm{d}$ & $-\mathrm{c}$ \\
$2661^{\mathrm{h}}$ & $-\mathrm{b}$ & $-\mathrm{d}$ & $-\mathrm{d}$ & $-\mathrm{d}$ & $-\mathrm{d}$ & $-\mathrm{d}$ \\
$2665 \mathrm{~g}, \mathrm{~h}$ & $-\mathrm{b}$ & $-\mathrm{d}$ & $-\mathrm{c}$ & $-\mathrm{a}$ & $0.9 \%$ & - \\
$2658^{\mathrm{f}}$ & $-\mathrm{b}$ & $-\mathrm{a}$ & $-\mathrm{c}$ & $-\mathrm{c}$ & - & $-\mathrm{a}$ \\
$2660^{\mathrm{h}}$ & $-\mathrm{b}$ & $-\mathrm{d}$ & $-\mathrm{d}$ & $-\mathrm{d}$ & $0.3 \%$ & $-\mathrm{d}$ \\
$2663 \mathrm{~g}$ & $-\mathrm{a}$ & $-\mathrm{d}$ & $-\mathrm{c}$ & $-\mathrm{a}$ & $-\mathrm{b}$ & - \\
$2657 \mathrm{~g}, \mathrm{~h}$ & $-\mathrm{b}$ & - & $-\mathrm{c}$ & $-\mathrm{a}$ & $0.5 \%$ & - \\
$2662^{\mathrm{h}}$ & $-\mathrm{b}$ & $-\mathrm{d}$ & $-\mathrm{d}$ & $-\mathrm{d}$ & $0.1 \%$ & $-\mathrm{d}$ \\
$2664 \mathrm{~g}, \mathrm{~h}$ & $-\mathrm{a}$ & $-\mathrm{d}$ & $-\mathrm{c}$ & $-\mathrm{a}$ & $0.7 \%$ & - \\
\hline
\end{tabular}

${ }^{\mathrm{a}} \mathrm{Abundant}$, peak area comparable to pure material.

${ }^{\mathrm{b}}$ Common.

$\mathrm{c}_{\text {Trace. }}$

d Not detected.

${ }^{\mathrm{e}}$ The area ratio of the $9.7 \AA$ todorokite to $7.2 \AA$ birnessite peak in this sample is 0.30 , suggesting mostly birnessite is present.

${ }^{\mathrm{f}}$ The corresponding peak area ratio in this sample is 18.0 , suggesting the dominance of todorokite.

$\mathrm{g}_{\text {These samples were leached with buffered acetic acid prior to }}$ X-ray diffraction analysis to remove abundant biogenic calcite.

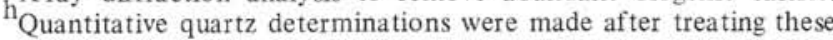
samples with strong acids and adding boehmite as an internal standard. Values listed are of weight percentage quartz in the dried, bulk sample, 
and GS 2662) exhibit only well-crystallized nontronite and a barely detectable amount of quartz in GS 2661 .

The chemical compositions of these nine samples are listed in Table 3. The data have been corrected for carbonate and salt contents. For $\mathrm{Al}, \mathrm{Si}, \mathrm{Mn}, \mathrm{Fe}, \mathrm{Ni}, \mathrm{Cu}$, $\mathrm{Zn}$, and $\mathrm{Ba}$ the weight percentage of each element that is leachable by the Chester and Hughes technique is listed as well. Triangular plots of $\mathrm{Si}-\mathrm{Fe}-\mathrm{Mn}$ (Figure 1), $\mathrm{Al}-\mathrm{Mn}-\mathrm{Fe}$ (Figure 2), Si-Fe-Ba $\times 10$ (Figure 3), $\mathrm{Cu}-\mathrm{Ni}-\mathrm{Zn}$ (Figure 4), and $(\mathrm{Cu}-\mathrm{Ni}-\mathrm{Zn}) \times 10-\mathrm{Mn}-\mathrm{Fe}$ (Figure 5) exhibit the intersample differences as well as distinctions between these samples and near-surface sample data from the mounds area and other parts of the Nazca plate.

\section{Manganese Mobilization}

Figures 1, 2, and 5 also demonstrate the remobilization of manganese which is a ubiquitous feature of sedimentation in this region. Because of the relatively large amount of oxidizable biogenic debris that reaches the bottom in this region, the sediments become reduced with depth. In cores from the region, the surface sediments are brown in color and become gray-green at depths of 10 to $30 \mathrm{~cm}$. This color boundary marks the level where sufficient oxygen is used up for oxidized manganese to be reduced to $\mathrm{Mn}^{+2}$ and thereby solubilized. The variations in Mn enrichments shown by the downcore and surface-sediment fields of Figures 1 and 2 reflect variations in the upward mobilization and deposition of manganese in the surface layer. $\mathrm{Ni}$ is also enriched in the surface sediments (Figure 4).

It is difficult to distinguish the Mn enrichment which is due to reductive mobilization from that due to the formation of $\mathrm{Mn}$ phases that have precipitated from hydrothermal solutions in the mounds area. Todorokite and birnessite crusts that have been recovered from the mounds surfaces, however, have much higher $\mathrm{Mn} / \mathrm{Ni}$ values than those observed in surface sediments. In the hydrothermal crusts, the average $\mathrm{Mn} / \mathrm{Ni}$ ratio is 3000 (Corliss et al., 1978 and unpublished data), whereas the corresponding value for surface sediments away from the mounds is 125 . This suggests that mixtures of hydrothermal Mn phases and the typical carbonate ooze of the region can be distinguished from near-surface enrichment due to remobilization, by $\mathrm{Mn} / \mathrm{Ni}$ values and possibly other minor-element relationships.

\section{Normative Composition of the DSDP Samples}

To evaluate further the chemical composition of these samples, a series of mass-balance equations was formulated which would model the data in terms of a mixture of seven possible "phases": (1) biogenic calcite, (2) biogenic opal, (3) hydrothermal nontronite, (4) hydrothermal birnessite-todorokite, (5) hydrogenous manganese oxides, (6) detrital silicates, and (7) barite. For each sample, nine mass-balance equations were written in the form:

$X_{C} C+X_{O} O+X_{N} N+X_{T} T+X_{M} M+X_{D} D+X_{B} B=X_{S}$,

where $C, O, N, T, M, D$, and $B$ refer to the weight fraction of calcite, opal, nontronite, todorokite, hydrogenous manganese oxides, detrital silicates, and barite, respectively. $X$ is the content of any chemical species in the seven phases considered and in the bulk samples. Ideal compositions for these components were taken from published data on pure samples (Corliss et al., 1978; Lyle et al., 1977; van Bennekom and van der Gaast,

TABLE 3

Compositional Data Corrected for Carbonate and Salt Contents ${ }^{\mathrm{a}}$

\begin{tabular}{|c|c|c|c|c|c|c|c|c|c|c|}
\hline & \multicolumn{4}{|c|}{ Hole 424} & \multicolumn{3}{|c|}{ Hole $424 \mathrm{~A}$} & \multicolumn{3}{|c|}{ Hole 424 B } \\
\hline & GS2659 (A) & GS2659 (B) & GS2661 & GS2665 & GS2658 & GS2660 & GS2663 & GS2657 & GS2662 & GS2664 \\
\hline \multicolumn{11}{|c|}{ Major elements (\%) } \\
\hline Al & 0.073 & 0.11 & $0.11(0)$ & $6.21(3.3)$ & $2.03(6.4)$ & $0.018(0)$ & $2.78(6.0)$ & $3.54(9.7)$ & $0.33(0)$ & $4.98(3.9)$ \\
\hline $\mathrm{Si}$ & 25.5 & 0.62 & $23.9(0)$ & $24.5(0)$ & $18.3(0)$ & $25.1(0)$ & $20.0(0)$ & $25.0(0)$ & $24.2(0)$ & $23.8(0)$ \\
\hline $\mathrm{Mn}$ & 0.136 & 49.02 & $0.092(67)$ & $1.84(82)$ & $14.3(98)$ & $0.068(28)$ & $2.99(97)$ & $1.86(84)$ & $0.036(25)$ & $1.84(100)$ \\
\hline $\mathrm{Fe}$ & 22.4 & 0.41 & $22.7(2.6)$ & $7.87(20)$ & $12.2(8.0)$ & $20.2(1.8)$ & $10.8(12)$ & $6.0(1.2)$ & $20.5(1.7)$ & $8.11(16)$ \\
\hline $\mathrm{CaCO}_{3}$ & 0.00 & 0 & 0.00 & 77.7 & 8.05 & 0.00 & 73.8 & 61.8 & 0.00 & 76.0 \\
\hline \multicolumn{11}{|c|}{ Minor elements (ppm) } \\
\hline $\mathrm{Sc}$ & - & - & 0,47 & 23 & 6.8 & 0.09 & 5.9 & 14 & 0.14 & 20 \\
\hline $\mathrm{Cr}$ & - & - & 5.4 & 58 & 22 & 2.5 & 16 & 50 & 3.2 & 54 \\
\hline $\mathrm{Co}$ & - & - & 0.79 & 65 & 13 & 4.2 & 7.6 & 25 & 1.2 & 27 \\
\hline $\mathrm{Ni}$ & 0.0 & 109 & 0.0 & 441 (59) & $163(76)$ & $6.5(0)$ & $16.1(100)$ & $351(45)$ & 0.022 & $159(90)$ \\
\hline $\mathrm{Cu}$ & 8.6 & 36 & $8.2(48)$ & $359(70)$ & $117(73)$ & $3.7(100)$ & $70(100)$ & $381(69)$ & $5.3(100)$ & $217(81)$ \\
\hline $\mathrm{Zn}$ & 29 & 103 & $26(0)$ & $429(21)$ & $136(66)$ & $24(43)$ & $152(100)$ & $740(50)$ & $23(0)$ & $410(49)$ \\
\hline As & - & - & - & 12 & 5.0 & 0.94 & - & - & 1.2 & 9.3 \\
\hline $\mathrm{Sb}$ & - & - & 0.51 & 10 & 10 & 1.1 & 13 & 14 & 0.96 & 3.1 \\
\hline $\mathrm{Ba}$ & 19 & 2775 & $93(45)$ & $8690(24)$ & $3010(47)$ & $21(0)$ & $369(0)$ & $8880(21)$ & $33(0)$ & $3820(16)$ \\
\hline $\mathrm{Hf}$ & - & - & - & 2.7 & 0.58 & - & 1.4 & 1.1 & - & 2.0 \\
\hline Th & - & - & - & 4.2 & 1.1 & - & 3.0 & 1.9 & & 3.2 \\
\hline \multicolumn{11}{|c|}{ Rare earth elements (ppm) } \\
\hline $\mathrm{La}$ & - & - & 0.54 & 32 & 7.2 & 0.27 & 14 & 20 & 0.19 & 31 \\
\hline $\mathrm{Ce}$ & - & - & 0.56 & 69 & 8.3 & 0.47 & 17 & 20 & 0.34 & 86 \\
\hline $\mathrm{Nd}$ & - & - & - & 58 & 11 & - & - & - & - & 70 \\
\hline $\mathrm{Sm}$ & - & - & 0.14 & 5.6 & 1.7 & 0.027 & 2.4 & 3.7 & 0.024 & 10 \\
\hline $\mathrm{Eu}$ & - & - & 0.031 & 1.4 & 0.41 & 0.029 & 0.63 & 1.1 & 0.019 & 3.2 \\
\hline $\mathrm{Tb}$ & - & - & 0.042 & 1.3 & 0.28 & - & 0.51 & 0.63 & - & 2.8 \\
\hline $\mathrm{Yb}$ & - & - & 0.31 & 5.5 & 1.4 & - & 3.4 & 3.9 & 0.092 & 18 \\
\hline Lu & - & - & 0.075 & 1.2 & 0.23 & 0.0068 & 0.60 & 0.52 & 0.0078 & 3.3 \\
\hline
\end{tabular}

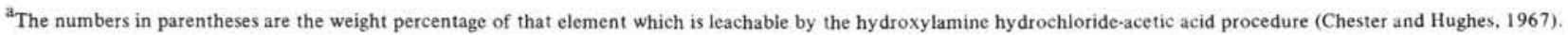




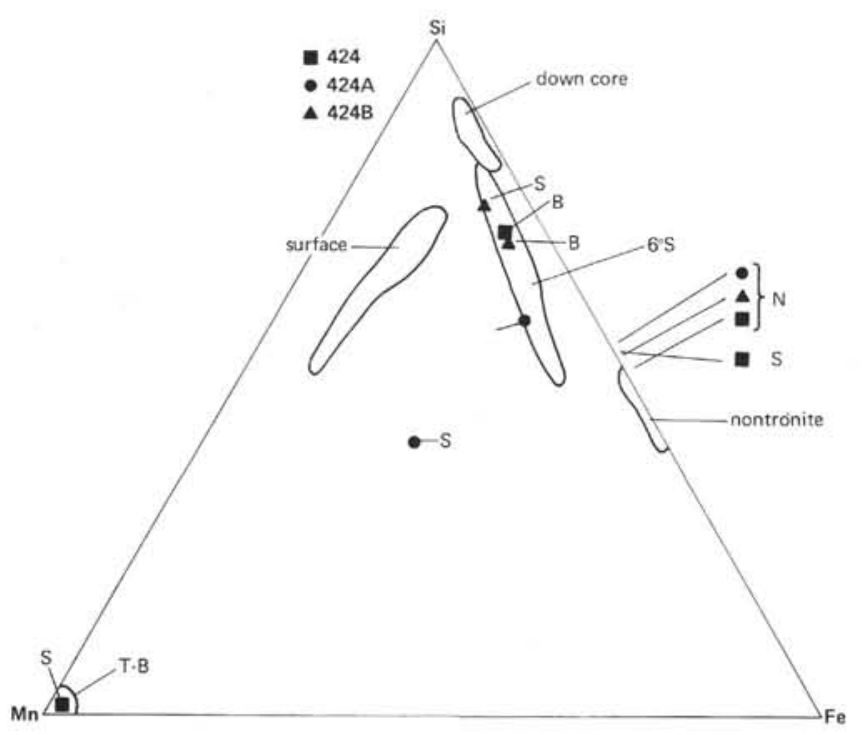

Figure 1. Si-Fe-Mn ternary diagram showing the relationships between the surficial $(S)$, nontronite $(N)$, and basal (B) sediments of Holes 424, 424A, and $424 B$. For comparison, data fields are included for: (1) typical surface sediments $(0$ to $5 \mathrm{~cm}$ ) recovered within $10 \mathrm{~km}$ of the mounds field (labeled "surface"; unpublished data), (2) downcore (5 to $300 \mathrm{~cm}$ ) samples from the same area (labeled "downcore"; unpublished data), (3) surface metalliferous sediments from $6^{\circ} \mathrm{S}$ on the East Pacific Rise (labeled $6^{\circ} \mathrm{S}$; unpublished data), and (4) dredged samples and Alvin submersible samples from the mounds (labeled $T-B$ for todorokite-birnessite and nontronite; Corliss et al., 1978, and unpublished data).

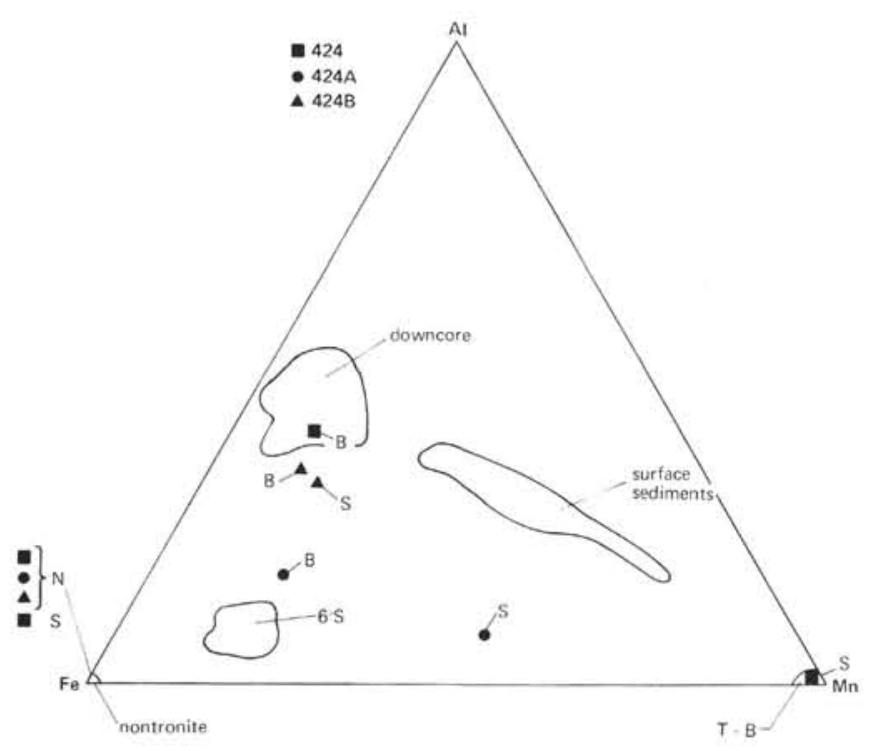

Figure 2. Al-Mn-Fe ternary diagram of the same samples and data fields as Figure 1.

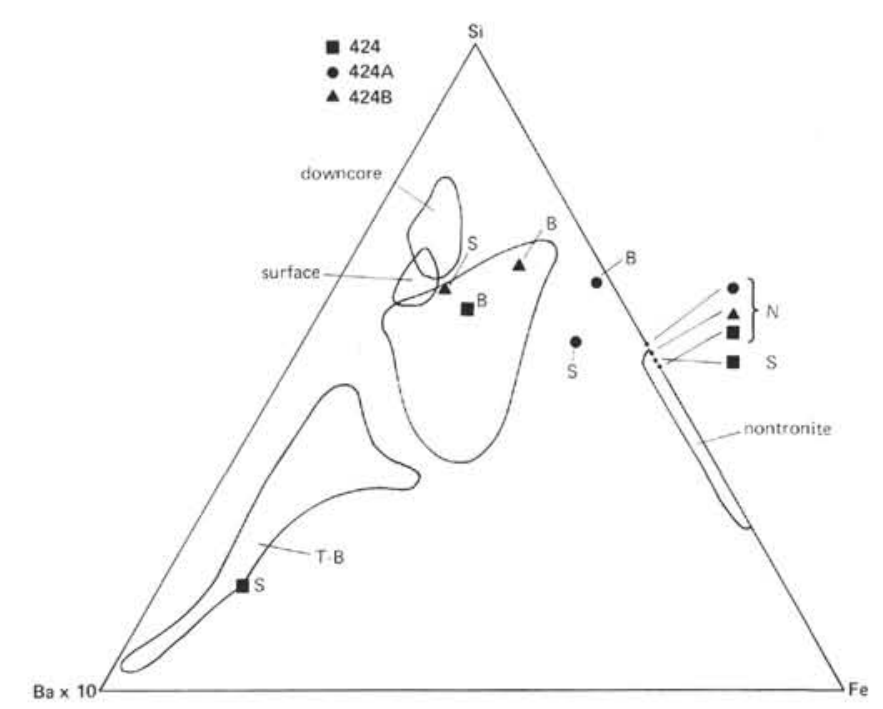

Figure 3. Si-Fe-Ba ternary diagram of the same samples and data fields as Figure 1.

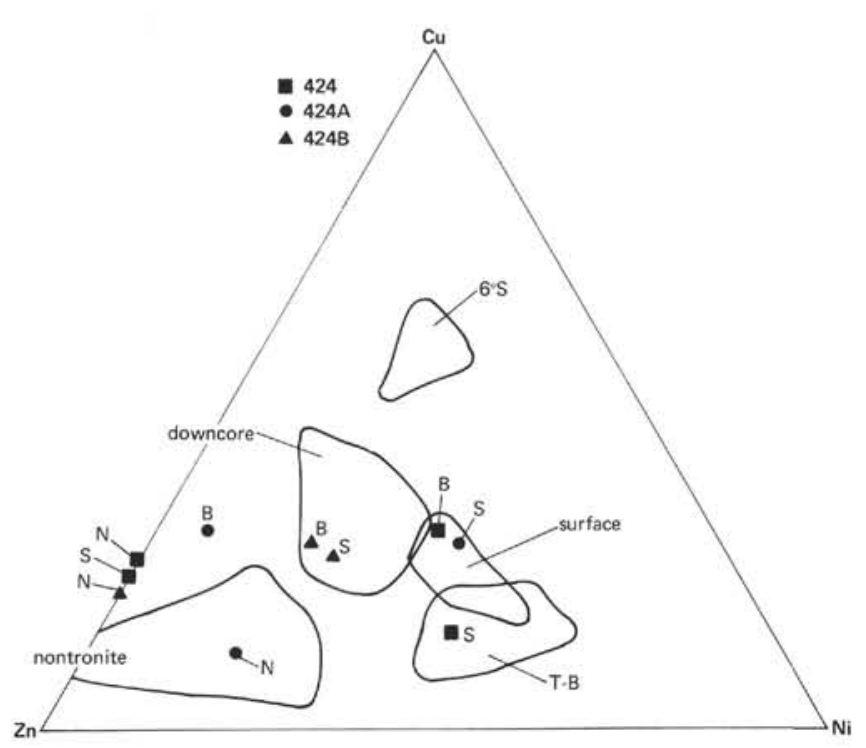

Figure 4. $\mathrm{Cu}-\mathrm{Ni}-\mathrm{Zn}$ ternary diagram of the same samples and data fields as Figure 1.

1976; Poldervaart, 1955; Church, 1968). We have used the most abundant elements analyzed in our samples $\mathrm{Al}, \mathrm{Si}, \mathrm{Ca}, \mathrm{Mn}, \mathrm{Fe}, \mathrm{Ni}, \mathrm{Cu}, \mathrm{Zn}$, and $\mathrm{Ba}$ - to set up nine linear equations of the forementioned type. In each set of equations the weight fraction of the seven phases are unknowns, and the composition of these phases is considered uniform and equal to the value taken from literature measurements of end-member phases. The assumed content of nine elements in each of the seven phases results in a matrix of 63 compositional coefficients (Table 4).

We have solved these linear equations with a linear programming package which utilizes the simplex al- 


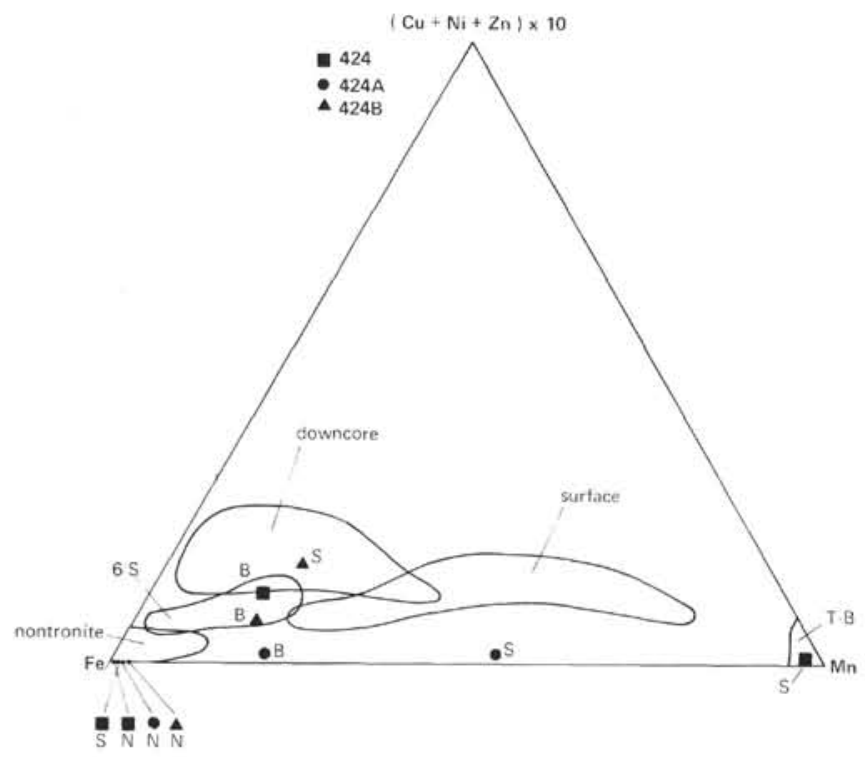

Figure 5. $\mathrm{Cu}+\mathrm{Ni}+\mathrm{Zn}-\mathrm{Mn}-\mathrm{Fe}$ ternary diagram of the same samples and data fields as Figure 1.

TABLE 4

Compositions (in ppm) of the Pure "Phases" Used in the Normative Analysis

\begin{tabular}{lrrrrrrr}
\hline & Calcite & \multicolumn{1}{c}{ Opal } & Nontronite & $\begin{array}{c}\text { Todorokite- } \\
\text { Birnessite }\end{array}$ & $\begin{array}{r}\text { Authigenic } \\
\text { Mn Oxides }\end{array}$ & $\begin{array}{r}\text { Detrital } \\
\text { Silicates }\end{array}$ & Barite \\
\hline $\mathrm{Al}$ & 390 & 775 & 100 & 1500 & 2000 & 84,000 & 0 \\
$\mathrm{Si}$ & 0 & 383,400 & 240,000 & 7000 & 8000 & 252,000 & 0 \\
$\mathrm{Ca}$ & 392,400 & 0 & 800 & 13,000 & 12,000 & 35,000 & 400 \\
$\mathrm{Mn}$ & 8 & 5 & 1500 & 510,000 & 450,000 & 1300 & 0 \\
$\mathrm{Fe}$ & 40 & 380 & 232,000 & 1400 & 25,000 & 58,800 & 0 \\
$\mathrm{Ni}$ & 5 & 15 & 2.7 & 120 & 4000 & 130 & 0 \\
$\mathrm{Cu}$ & 5 & 20 & 2 & 30 & 2000 & 120 & 0 \\
$\mathrm{Zn}$ & 5 & 31 & 28 & 110 & 2800 & 1120 & 240 \\
$\mathrm{Ba}$ & 150 & 775 & 68 & 1200 & 1125 & 670 & 588.400 \\
\hline & & & & & & & \\
\hline
\end{tabular}

gorithm (Scheurman, 1972). For each sample that model phase composition was determined which minimizes the difference between the observed elemental abundances and the model abundance. The optimal solution is one in which the sum of these elemental residuals is minimized. Negative solutions for phase abundances were prohibited in the formulation; however, negative residuals were permitted. The model has been tested by application to the total surface and downcore sample set with excellent results. Nearly all samples could be fitted with residuals less than $200 \mathrm{ppm}$. In addition, the measured $\mathrm{CaCO}_{3}$ content compares very favorably with the model-computed $\mathrm{CaCO}_{3}$ content (Figure 6 and Table 3 ) and is compatible with the qualitative X-ray diffraction data (Table 2). A similar formulation has been used before to determine the phase content of a Nazca plate sediment sample (Dymond and Eklund, 1978). The model bears strong resemblance to the "mixing models" used in igneous petrology (Byran et al., 1969), although most of these use regression analysis rather than linear programming. Our model can be considered a normative sediment analysis with the basic assumption that any sample is

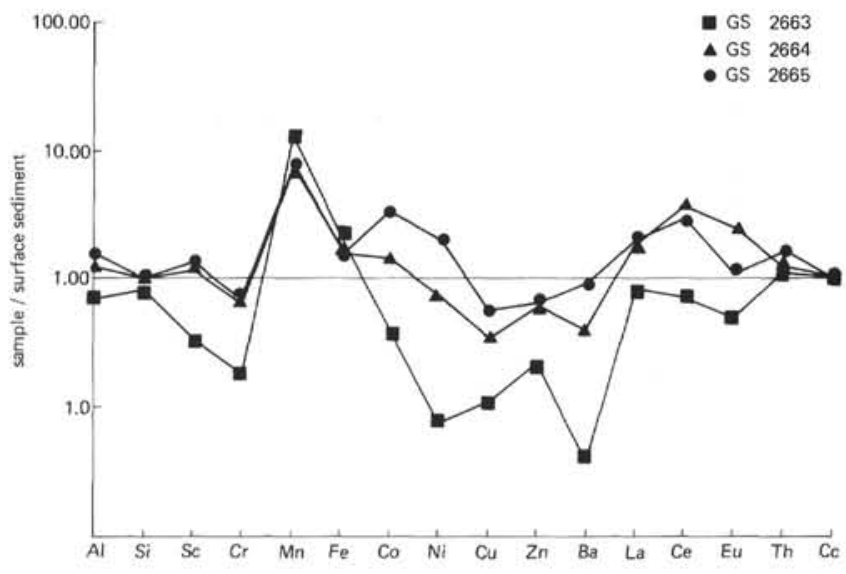

Figure 6. Elemental normalization plot for the three basal samples of Holes 424, 424A, and 424B. The data have been normalized to a typical near-surface sample taken from just outside the mounds area. The selected sample is Pleiades $38 \mathrm{G}, 96-97 \mathrm{~cm}$, which is below the depth of manganese enrichment due to remobilization. Cc refers to calcium carbonate.

composed of mixtures of these "phases" of known composition.

The results of this analysis (Figure 6) demonstrate that the three basal sediments are carbonate oozes with significant detrital contents and lesser opal and nontronite contents. The basal sediments are somewhat more carbonate-rich and opal-depleted than near-surface sediments. The green layer sampled at mid-depths in each core (GS 2661, GS 2660, and GS 2662) is essentially pure nontronite, although the normative analysis indicates GS 2660 and GS 2662 to have opal contents of respectively 10.8 and 7.4 per cent, reflecting the higher $\mathrm{Si} / \mathrm{Fe}$ values for these samples (Figure 1, Table 2). The surficial samples from Holes 424 (GS 2659) and 424A (GS 2658) are mixtures of nontronite and todorokite-birnessite with very little carbonate. The near-surface sample from GS 2657 has a normative suite of minerals which is very much like other near-surface samples from the general area, with little or no contribution of the hydrothermal manganese or iron phases.

\section{Origin of Basal Sediments}

The three basal samples and the near-surface samples have $\mathrm{Mn}$ and $\mathrm{Fe}$ contents that are higher than those observed in surface and downcore samples not directly related to the mounds field (Table 3 , Figure 7). The composition of these samples (GS 2657, GS 2658, GS 2663 , GS 2664 , and GS 2665) can be explained as being mixtures of the normal pelagic sediments - represented by the surface and downcore fields in Figures 1, 2, 3, 4, and 5 - and hydrothermal manganese and iron phases.

We suspect that the enrichments in $\mathrm{Mn}$ and $\mathrm{Fe}$ in the three basal samples result from ridge-crest hydrothermal processes similar to those that are believed to form the metalliferous sediments found on the East Pacific 

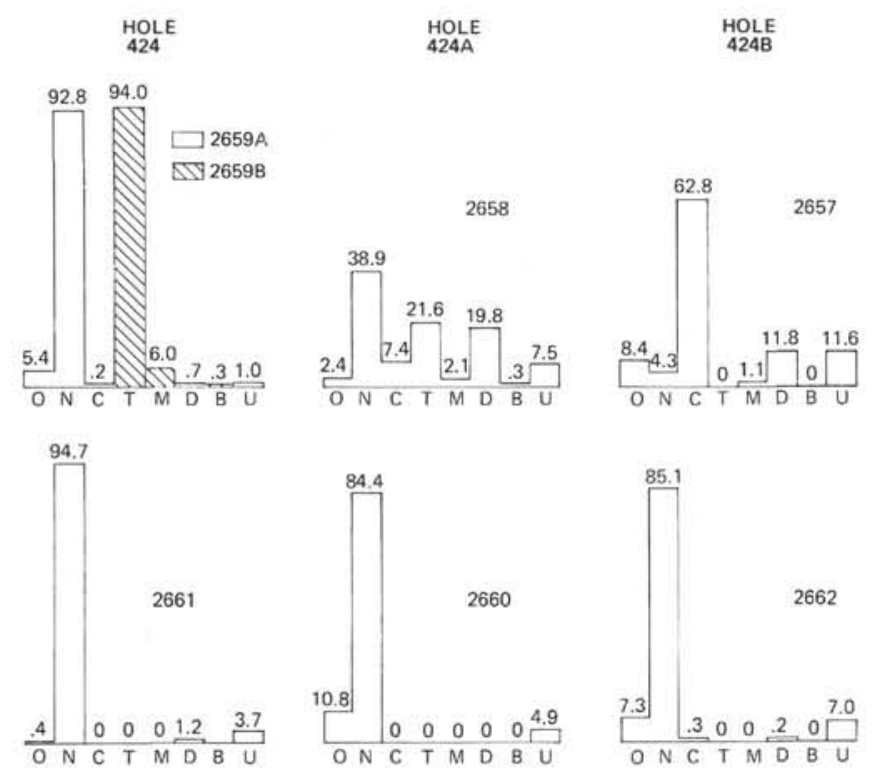

\begin{tabular}{l|l}
1.42 .9 \\
$O N$ N C T M D B U
\end{tabular}
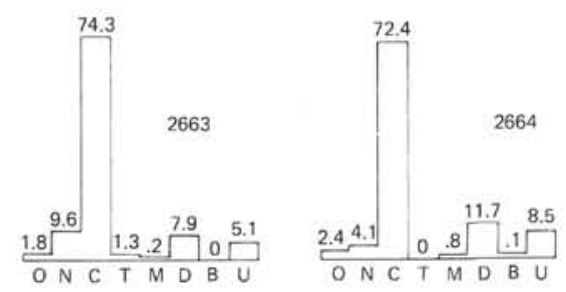

Figure 7. Histograms of the normative sediment composition for Holes 424, 424A, and 424B. O, N,C,T, $M, D, B$, and $U$ refer to opal, nontronite, calcite, todorokite-birnessite, hydrogenous manganese oxides, detrital silicates, barite, and unknown phases, respectively. The numbers above each histogram are the computed percentages of that phase according to the normative model.

Rise (EPR) rather than by processes associated with the formation of the mounds. The reasons for this distinction are as follows:

1) The composition of the basal deposits have an $\mathrm{Fe} / \mathrm{Mn}$ ratio and minor element abundances that are similar to metalliferous sediments from $6^{\circ} \mathrm{S}$ on the EPR (Figures 1, 3, and 5). There are, however, differences in $\mathrm{Cu} / \mathrm{Ni}$ ratios (Figure 4) and $\mathrm{Al}$ contents (Figure 2).

2) The reducing acid-leachable fraction of $\mathrm{Fe}$ in the basal sediments is 12 to 20 per cent of the total iron (Table 2). In surface sediments where the iron is largely in crystalline detrital phases and in the well-crystallized nontronite, the percentage of leachable iron is much lower $(1.2$ to $8.0 \%)$. This suggests the excess $\mathrm{Fe}$ in the basal sediments is in the form of poorly crystalline or amorphous hydroxyoxides which could form by oxidative precipitation of $\mathrm{Fe}$ exiting from hydrothermal springs at the spreading center.

\section{Hypotheses for the Origin of the Mounds and Nontronite}

\section{A. Nontronite Layer Deposition}

Natland et al. (1979) have proposed that the nontronite was deposited relatively quickly as a layer 200,000 to 300,000 years ago and over an area larger than that presently covered by mounds. The source of the metals and silica presumably was the hydrothermal fluids formed by interaction with cooling basaltic crust. This hypothesis is like the one proposed for the chemically and mineralogically similar iron-montmorillonite facies which underlies the Red Sea thermal brines, because it requires direct precipitation from iron-and silica-rich hydrothermal solutions over a wide area (Bischoff, 1969). The theory accounts for the relatively uniform thickness and interbedded nature of nontronite layer in the three holes, the presence of a nontronite layer in Hole 424B (a supposedly off-mounds site), and the very pure nature of the nontronite layer. The mounds themselves are suggested to be nontronite material displaced upward along zones of weakness. The surficial manganese deposits are thought to indicate a change in hydrothermal fluid composition from a rockdominated system that produced nontronite to a present-day "water-dominated" system. In Figure 8A we have attempted to interpret the DSDP findings in terms of this hypothesis.

The theory does not adequately account for the very high heat/flow associated with the mounds and the presence of convective flow (Williams et al., 1979). Furthermore, if the nontronite forms continuous layers and the interbedded carbonates are continuous, an episodic shutting down of the hydrothermal deposits over the entire mounds area would be required to account for the observed interbedding. $\mathrm{FeO} / \mathrm{Fe}_{2} \mathrm{O}_{3}$ ratios measured in the nontronite layer of Hole 424 range from 0.01 to 0.05 (Donnelly, this volume) and are significantly lower than the average of 0.35 observed in Red Sea iron smectites (Bischoff, 1969). This suggests the redox conditions for deposition were different in the two areas and were only mildly reducing or oxidizing in the mounds area. Without the existence of a brine layer as found in the Red $\mathrm{Sea}$, it is difficult to envision the mechanism for precipitating or distributing the nontronite over as wide an area as suggested by this hypothesis (Note: the mounds field covers at least $380 \mathrm{~km}^{2}$, Williams et al., 1979).

With the exception of the Red Sea, other examples of the nontronite layer deposition proposed have not been observed. One might expect that in the area between the spreading center and the present mounds location, nontronite layer formation would be occurring today. No bottom-water thermal anomalies have been observed in this area despite the deep-tow and heat-flow thermistor surveys and the sediments in this region are carbonatesiliceous oozes of relatively uniform composition. 

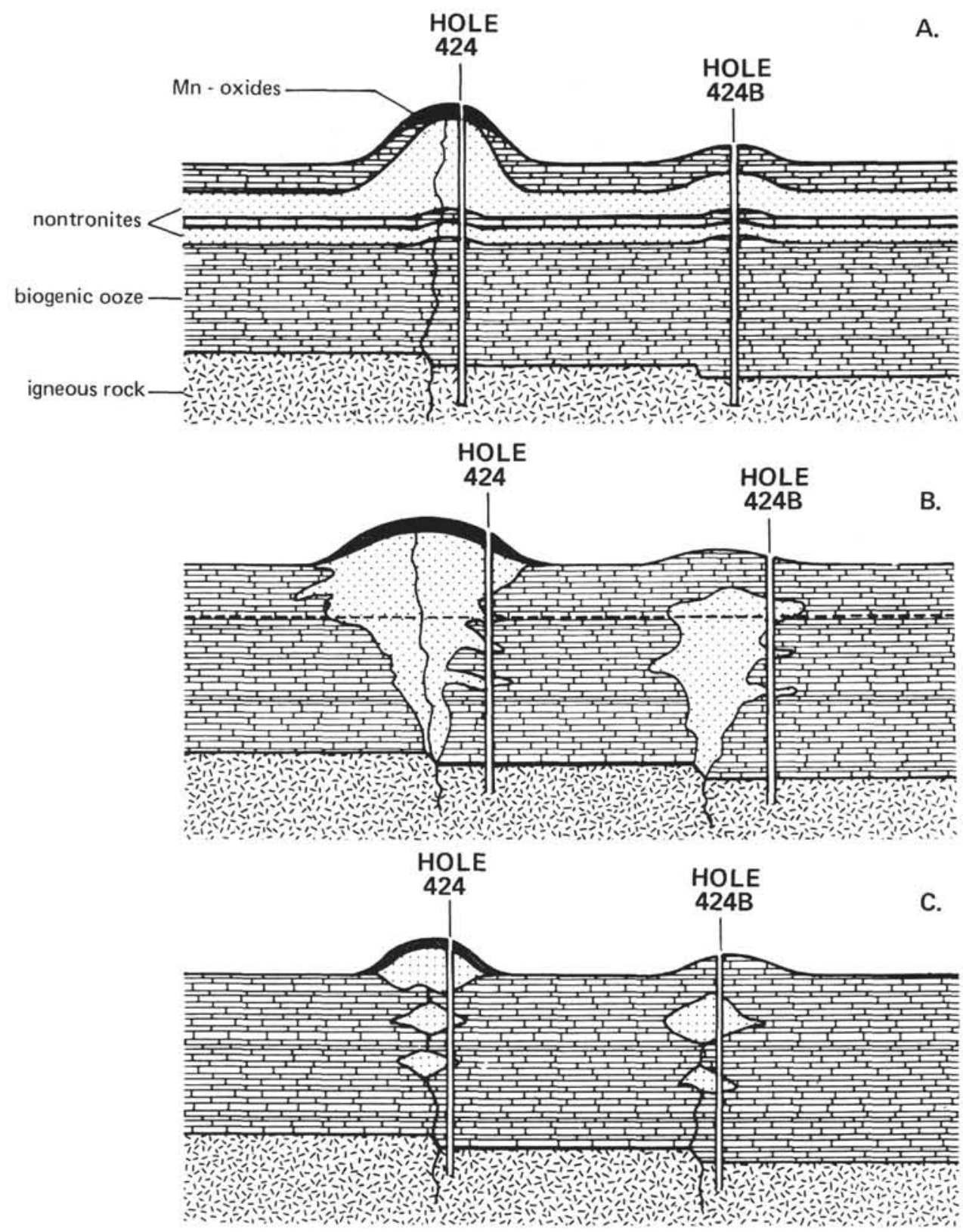

Figure 8. Three hypotheses for the formation of the sediment mounds and the nontronite layers. $(A)$ depicts early formation of a nontronite layer and later diapiric upwelling to form the mounds (after Natland et al., 1979). (B) represents a later replacement of biogenic ooze by nontronite (after Williams et al., 1979). The dashed line marks the time stratigraphy boundary when mound formation occurred (130,000 years B.P.) (C) shows mound formation by hydrothermal solutions passing through a near-surface redox gradient. The pod-like nature of the nontronite beds results from episodic flow of the hydrothermal fluid.

\section{B. Nontronite Replacement of Carbonate Ooze}

Williams et al. (1979) have pointed out that the age for initiation of nontronite deposition suggested by DSDP stratigraphy (200,000 to 300,000 years B.P.) is incompatible with the observed geographic distribution of the mounds. They argue that since no mounds are presently closer than $17 \mathrm{~km}$ (500,000-year-old crust) from the spreading center, the mounds, which overlie crust 630,000 years old, must have formed within the past 130,000 years. There should, therefore, be approximately 25 meters of ooze underlying any nontronite instead of the observed 10 to 15 -meter-thick basal carbonate section. It must be remembered that these arguments are based on the assumptions that nontronite deposition was essentially instantaneous and that the 
carbonate ooze has been deposited at a constant rate of $5 \mathrm{~cm} / 1000 \mathrm{y}$. Since a factor or two or more variations in carbonate sedimentation rate during the past 630,000 years are not unreasonable, the above arguments for the timing of nontronite deposition are questionable.

Williams et al. (1979) suggest that the nontronite may form internally by dissolution of carbonate and replacement of opal by nontronite. This hypothesis allows for very recent development of the nontronite layer and the mounds, and accounts for the lack of intermixed normal biogenic sediments into the nontronite. It does require, however, a considerable flux of elements into and out of the nontronite layer.

For example, assuming that the normal carbonate ooze had a bulk density, water content, and elemental composition similar to that observed in basal sediments, the transformation to nontronite requires an increase by a factor of approximately 3.5 for silica and 8.5 for Fe. In addition to leaching out all of the carbonate, the transformation to nontronite requires the loss of 85 per cent of the $\mathrm{Al}, 94$ per cent of the Sc, 94 per cent of the $\mathrm{La}, 74$ per cent of the $\mathrm{Co}$, and 99 per cent of the $\mathrm{Ba}$ which originally was present in the carbonate ooze. These elements, which are considered to be relatively immobile in a sedimentary environment, demonstrate the considerable dissolution of detritus and leaching of the normal sediment required by such an internal transformation. Quartz contents in some of the samples were measured by quantitative X-ray diffraction analysis (Table 2). The nontronite samples contain between 0 and 0.3 weight per cent quartz $(0.1 \%$ average) compared with 0.5 to 0.9 weight per cent $(0.1 \%$ average) for the surficial and basal samples. This implies that either the nontronite was deposited very rapidly and little detritus was included or that most of the detrital phases have been dissolved by hydrothermal solutions.

\section{Precipitation in an Oxidation-Reduction Gradient}

An alternative hypothesis for the formation of the hydrothermal nontronite and mounds deposits is that both are formed by precipitation of $\mathrm{Fe}$ and $\mathrm{Mn}$ phases from hydrothermal fluids which have been cooled and oxygenated just below the sediment/water interface. In this case, the ultimate source of metals and heat in these fluids is seawater/basalt interaction in the crust, whereas the loci for exiting solutions is controlled by faults in the basaltic basement. Short cores and crust-like samples recovered during the Alvin submersible dives in this area indicate that this process occurs today. A common sequence observed in Alvin sampling is 1 to $10 \mathrm{~cm}$ of very pure manganese crust (todorokite and birnessite) underlain by brownish crust-like material, which in turn is underlain by green, less consolidated material that is compositionally similar to the nontronite recovered by dredging (Corliss et al., 1978) and the nontronite samples studied here. In some cases, the intermediate brown layer is merely a more oxidized form of the nontronite; in others, it is the amorphous iron material described by Corliss et al. (1978).
This hypothesis, which would account for the observed sequence and the entire mounds deposits, suggests mounds grow by precipitation of the Mn phases at the surface and the nontronite or amorphous phases under the surface. The precipitation is controlled by the oxidation gradient, established by a balance between upward convection of oxygen-poor, hydrothermal fluids and downward diffusion of oxygen from bottom water. As manganese precipitates near the surface, the redox gradient migrates upward causing dissolution of manganese at the base of the crust and concomitant precipitation of nontronite. If convection of the hydrothermal fluid is relatively great, the iron phases will precipitate very close to the surface. If the flow diminishes, the oxidation gradient will be less steep and the iron phases will precipitate at greater depth.

The samples, heat flow measurements, and warm water collected by the submersible on the mounds are compatible with this process. If the process occurred during the past several hundred thousand years, it would account for the distribution of nontronite layers, with overlying manganese crust observed in the DSDP cores. The interbedded carbonate in the nontronite layers recovered would represent periods in which the hydrothermal flow stopped due to self-filling of the convective pathway or tectonic adjustments which change the hydrothermal plumbing system.

The uniform thickness of the basal carbonates suggests that the initiation of nontronite formation occurred simultaneously in the area of all three DSDP holes. This requires that the Hole 424B site be close enough to a hydrothermal vent to receive nontronite deposition. In light of observations from Alvin (Corliss et al., 1979; Williams et al., 1979) that some mounds, representing sites of hydrothermal deposition, were less than 1 meter high, we believe that undetected mounds or hydrothermal vents could exist in the vicinity of Hole 424B. Thus, all three holes could record the simultaneous initiation of hydrothermal activity by tectonic adjustment without requiring nontronite deposition in widespread layers.

Unless the hydrothermal nontronite is deposited rapidly, however, the theory does not account for the lack of admixed detrital and biogenic material. An essentially instantaneous deposition of hydrothermal phases would produce very pure nontronite, but would greatly increase the thickness of the sediment column. The total carbonate ooze thickness in the three cores is 8 to 13 meters less than the 30 meters expected for a constant deposition rate of $5 \mathrm{~cm} / 1000 \mathrm{y}$. Some or all of the missing carbonate sediment could be accounted for by variations in sedimentation rate in the area. Within a kilometer of the DSDP holes the sediment thickness varies between 22 and 30 meters (K. Crane, personal communication). Alternatively, it is possible that the carbonate ooze dissolves when it encounters the low- $p \mathrm{H}$ hydrothermal fluids under the Mn crusts. Dissolution of opal and precipitation as nontronite (Lyle et al., 1977) could remove biogenic opal as well; however, as already 
discussed, dissolution of refractory detrital phases is more problematical.

\section{CONCLUSIONS}

Although all three hypotheses considered here have some attraction, we prefer that of an advancing oxidation gradient. This hypothesis in itself may not account adequately for a long period of hydrothermal deposition without admixture of normal pelagic sediments; however, it does fit with the direct observations made with Alvin and provides a very plausible mechanism to fractionate the hydrothermal solutions into $\mathrm{Fe}$ and $\mathrm{Mn}$ phases. The most troublesome aspect of one of the alternative hypotheses - early nontronite layer formation - is the catastrophic outpouring of hydrothermal fluids which is implied. That theory does not explain the unusual occurrence of the mounds deposits and, if valid, one would expect sedimentation near many spreading centers to have nontronite layer deposition. We suspect the presence of mounds and nontronite is intimately linked to the fact that the Galapagos spreading center is in an area of unusually rapid pelagic sedimentation. The burial of recently formed oceanic crust causes exiting hydrothermal fluids to pass through a steady-state oxidation and thermal gradient. Where the hydrothermal fluids debouch directly onto the sea floor, as is probably the case on most of the slowly sedimenting East Pacific Rise, amorphous $\mathrm{Fe}$ and $\mathrm{Mn}$ hydroxyoxides form. The third hypothesis, replacement of normal pelagic sediments by hydrothermal phases, accounts nicely for the purity of the hydrothermal phases but requires dissolution of refractory detrital phases and mobilization of insoluble elements.

\section{ACKNOWLEDGMENTS}

We thank Drs. Joris Gieskes, Mitchell Lyle, and G. Ross Heath for reviewing the manuscript and the Leg 54 Scientific Party for providing the samples. Peggy Lawrence did the drafting and Roxanne Roderick prepared the manuscript. This research was funded by the International Decade of Ocean Exploration Office, National Science Foundation, Grant OCE 77-23978.

\section{REFERENCES}

Bischoff, J. L., 1969. Red Sea geothermal brine deposits: their mineralogy, chemistry, and genesis. In Degans, E. T. and Ross, D. A. (Eds), Hot Brines and Recent Heavy Metal Deposits in the Red Sea: New York (Springer-Verlag), p. 368.

Bryan, W. B., Finger, L. W., and Chayes, F., 1969. Estimating proportions in petrographic mixing equations by least squares approximation. Science, v. 163, p. 926.
Chester, R. and Hughes, M. J., 1967. A chemical technique for the separation of ferromanganese minerals, carbonate minerals and absorbed trace elements from pelagic sediments. Chem. Geol., v. 2, p. 249.

Church, T. M., 1968. Marine barite, Ph.D. dissertation, University of California, San Diego.

Corliss, J. B., Dymond, J., Lyle, M., and Crane, K., 1978. The chemistry of hydrothermal mounds near the Galapagos Rift. Earth Planet. Sci. Lett., v. 40, p. 12.

Corliss, J. B., Dymond, J., Gordon, L. I., Edmond, J. M., von Herzen, R. P., Ballard, R. D., Green, K., Williams, D., Bainbridge, A., Crane, K., and van Andel, T. H., 1979. Submarine thermal springs on the Galapagos rift. Science, v. 203 , p. 1073 .

Dymond, J., Corliss, J. B., and Heath, G. R., 1977. History of metalliferous sedimentation at deep sea drilling site 319 in the South Eastern Pacific. Geochim. Cosmochim. Acta, v. 41, p. 741 .

Dymond, J. and Eklund, W., 1978. A microprobe study of metalliferous sediment components. Earth Planet. Sci. Letter., v. 40, p. 243.

Gordon, G. E., Rundle, K., Goles, G. G., Corliss, J. B., Benson, M. H., and Oxley, S. S., 1968. Instrumental neutron activation analysis of standard rocks with high resolution $\gamma$-ray detectors. Geochim. Cosmochim. Acta, v. 32, p. 369.

Klitgord, K. S. and Mudie, J. D., 1974. The Galapagos spreading center: a near-bottom geophysical survey. Geophys. J. Roy. Astron. Soc., v. 38, p. 563.

Lonsdale, P., 1977. Deep tow observations at the mounds abyssal hydrothermal field, Galapagos Rift. Earth Planet. Sci. Lett., v. 36, p. 92.

Lyle, M., Dymond, J., and Heath, G. R., 1977. Coppernickel-enriched ferromanganese nodules and associated crusts from the Bauer Basin, northwest Nazca Plate. Ibid., v. 35, p. 55 .

Natland, J. H., Rosendahl, B., Hekinian, R., Dmitriev, Y., Fodor, R. V., Goll, R. M., Hoffert, M., Humphris, S. E., Mattey, D. P., Petersen, N., Roggenthen, W., Schrader, E. L., Srivastava, R. K., and Warren, N., 1979. Galapagos hydrothermal mounds: stratigraphy and chemistry revealed by deep sea drilling, in preparation.

Poldervaart, A., 1955. Chemistry of the Earth's crust. Geol. Soc. Am. Spec. Paper 62, p. 119-144.

Scheurman, L., 1972. REX, version I linear programming system, Oregon State University Computer Center, Corvallis, Oregon.

van Bennekom, A. J. and van der Gaast, S. J., 1976. Possible clay structures in frustules of living diatoms. Geochim. Cosmochim. Acta., v. 40, p. 1149.

Williams, D. L., Green, K., van Andel, T. R., von Herzen, R. P., Dymond, J. R., and Crane, K., 1979. The hydrothermal mounds of the Galapagos Rift: observations with DSRV ALVIN and detailed heat flow studies, in preparation. 